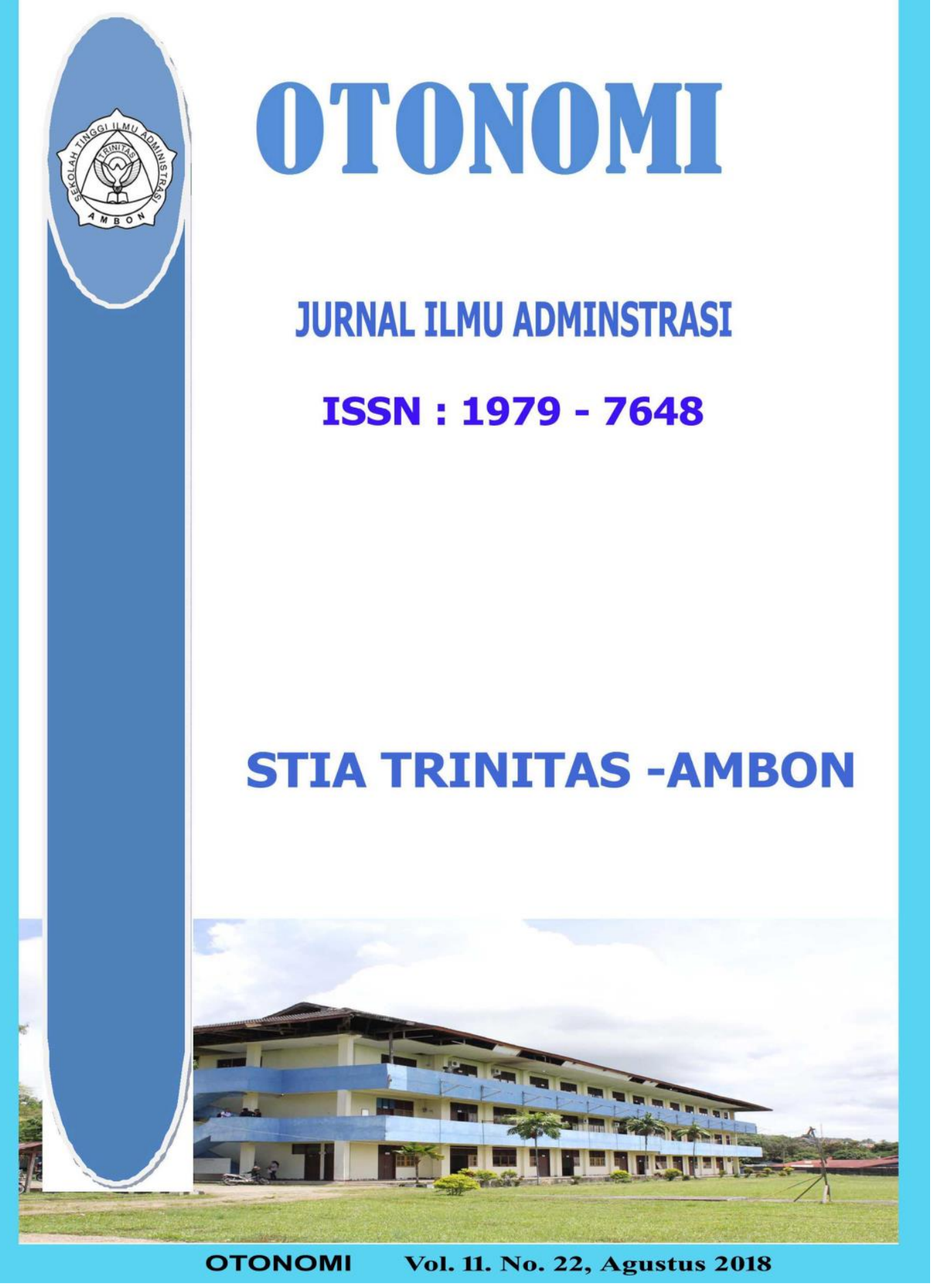




\title{
ANALISIS NILAI-NILAI BUDAYA DUAN LOLAT \\ BERBASIS KEARIFAN LOKAL PADA MASYARAKAT TANIMBAR DI KABUPATEN MALUKU TENGGARA BARAT
}

\author{
Oleh \\ Amtai Alaslan, S.IP, M.Si \\ (STIA Saumlaki)
}

\begin{abstract}
This study aims to describe, analyze the cultural values of duan lolat based on local wisdom in the Tanimbar community in West Southeast Maluku Regency (MTB). The research method used is descriptive qualitative research, data is collected through interviews, observation and literature studies as well as tracking related research results.

The results of the study show that duan-lolat cultural values based on local wisdom remain alive and take root in the Tanimbar community as an entity or characteristic of the Tanimbar community, so they can contribute positively to the provision of development in this country. The spirit of mutual cooperation, social solidarity, compassion, independence and consensus in resolving community conflicts which are actually duan-lolat values, starting from being corrected (deconstructed) the meaning exchanged for the low value of duan-lolat, can also be transformed into the wisdom of the Tanimbar community.
\end{abstract}

\section{Keywords: Cultural Value, Duan Lolat and Local Wisdom}

\begin{abstract}
Abstrak
Penelitian ini bertujuan untuk mendiskripsikan, menganalisis Nilai-nilai budaya duan lolat berbasis kearifan lokal pada masyarakat Tanimbar di Kabupaten Maluku Tenggara Barat (MTB). Metode penelitian yang digunakan adalah penelitian deskriptif kualitatif, data dikumpulkan melalui wawancara, observasi dan studi pustaka serta penelusuran hasil-hasil penelitian yang terkait.

Hasil penelitian menunjukan nilai- nilai budaya duan-lolat yang berbasis kearifan lokal tetap hidup dan mengakar di masyarakat Tanimbar sebagai entitas atau ciri khas dari masyarakat Tanimbar, sehingga dapat memberikan kontribusi positif dalam mengisi pelaksanaan pembangunan di negeri ini. Semangat gotong royong, solidaritas sosial, bela rasa, kemandirian dan kemufakatan dalam menyelesaikan konflik masyarakat yang sejatinya merupakan nilai-nilai duan-lolat muali mengalami pergeseran (dekonstruksi) makna sehingga menyebabkan rendahnya derajat nilai duan-lolat itu sendiri sebagai sebuah kearifan lokal yang dianut oleh masyarakat Tanimbar.
\end{abstract}

\section{Kata Kunci : Nilai Budaya, Duan Lolat dan Kearifan Lokal}




\section{PENDAHULUAN}

Modernisasi dan globalisasi masyarakat gemeinschaft telah berubah wajah menjadi masyarakat gesellschaft yang mengandalkan institusi negara dalam memecahkan persoalan yang mereka hadapi. Proses cenderung mengedepankan prinsip-prinsip rasionalitas dan nilai-nilai hukum positif yang berlaku di Negara tersebut. Perubahan yang terjadi pada masyarakat yang kebudayaannya sudah maju atau kompleks ini, biasanya terwujud dalam proses penemuan (discovery), penciptaan baru (invention), dan melalui proses penyebaran unsur-unsur kebudayaan (difusion). Perkembangan tersebut merupakan proses modernisasi dalam suatu masyarakat yang menciptakan keinginan dan harapan-harapan baru yang menggususur pengetahuan dan teknologi lokal serta seluruh sistem sosial budaya (kearifan local) masyarakatnya.

Disadari atau tidak peristiwa globalisasi ini yang berlangsung secara masif diseluruh belahan Dunia termasuk di negeri inilah, yang telah membawa dampak tersendiri bagi perkembangan nilai budaya duan-lolat pada masyarakat Tanimbar di Kabupaten Maluku Tenggara Barat (MTB). Budaya Duan Lolat yang sejatinya merupakan suatu sistem budaya yang ada untuk memenuhi kebutuhan dan kepentingan bersama sebagai sebuah sosial capital dalam kegiatan Pesta perkawinan, pembangunan rumah dan pesta lainnya dengan nilai-nilai yang terkandung didalammnua seperti semangat gotong royong, partisipasi, solidaritas sosial untuk mewujudkan kesejahteraan bersama sekaligus dapat dijadikan media untuk meredam konflik jika terjadi perselisihan antara dua belah pihak mulai mengalami pergeseran.

Dengan hadirnya globalisasi yang kurang terfilterisasi dengan baik menyebabkan budaya Duan Lolat sedikit demi sedikit mulai hilang dalam kebiasaan masyarakat Tanimbar khususnya di Kota Saumlaki. Bahkan saat ini nilai-nilai yang terkandung dalam budaya duan-lolat telah jauh menyimpang dari maknanya yang sebenarnya. Dimana telah terjadi dekonstruksi makna duan-lolat di masyarakat sehingga tanggungan adat yang tadinya dilakukan dengan semangat gotong royong demi berbela rasa solidaritas telah bergeser menjadi semangat konsumtif.

Dengan merujuk pada pendapat tersebut, dapat dikatakan bahwa pergeseran makna duan-lolat ini telah menyebabkan rendahnya derajat nilai duan-lolat itu sendiri sebagai sebuah kearifan lokal yang dianut oleh masyarakat Tanimbar. Situasi anomali seperti ini menunjukan bahwa masyarakat Tanimbar tengah menghadapi persoalan serius, yang jika tidak segera ditangani akan menjadi "bom waktu" bagi keberlangsungan pembangunan itu sendiri. Untuk itu, diperlukan berbagai upaya 
perbaikan yang perlu dilakukan oleh setiap pemangku kepentingan. Salah satu upaya strategisnya adalah melakukan analisis, merekonstruksi dan melakukan penguatan terhadap nilai-nilai budaya duan-lolat yang berbasis kearifan lokal agar tetap hidup mengakar di masyarakat Tanimbar agar dapat memberikan kontribusi positif dalam mengisi pelaksanaan pembangunan di negeri ini.

\section{TINJAUAN PUSTAKA}

\section{Kearifan Lokal}

Kearifan lokal atau "local genius" merupakan istilah yang diperkenalkan oleh Wales (Rasid, 2014: 36) yaitu the sum of the cultural characteristics which the vast majority of a people have in common as a result of their experiences in early life. Selain itu, local genius menurut Wales yaitu kemampuan kebudayaan setempat dalam menghadapi pengaruh kebudayaan asing pada waktu kedua kebudayaan itu berhubungan" (Rosidi, 2011). Selain itu, Judistira (2008) menegaskan bahwa kebudayaan lokal adalah melengkapi kebudayaan regional, dan kebudayaan regional adalah bagian-bagian yang hakiki dalam bentukan kebudayaan nasional.

Berdasarkan pendapat di atas, kearifan lokal merupakan budaya yang dimiliki oleh masyarakat tertentu dan di tempat- tempat tertentu yang dianggap mampu bertahan dalam menghadapi arus globalisasi, karena kearifan lokal tersebut mengandung nilai-nilai yang dapat dijadikan sebagai sarana pembangunan masyarakat.

\section{Budaya Duan Lolat}

Hubungan kekerabatan duan-lolat ini oleh Drabbe (1928 dan 1989), Bohm (1995), Koritelu (2009), Pangemanan dan Bohm (2011), de Jonge dan van Dijk (2011), Lerebulan (2011), dan Wuritimur (2012) secara harafiah dijelaskan bahwa kata duan berarti tuan atau pemilik suatu barang. Tuan atau pemilik ini berfungsi sebagai pelindung terhadap barang itu. Sementara itu kata lolat berarti penerima suatu barang. Pelembagaan nilai duan-lolat terjadi pada proses perkawinan adat, dimana duan merupakan predikat yang diberikan kepada kelompok keluarga yang bertindak sebagai pemberi perempuan, sedangkan lolat adalah predikat bagi kelompok keluarga yang bertindak sebagai penerima perempuan. Sementara itu, dalam tatanan Budaya masyarakat Tanimbar dimaknai sebagai hububgaan kekerabatan dimana kata "Duan" berarti tanah atau Pemberi Dara (anak Perempuan) dan "Lolat" disimbolkan dengan hujan yang jatuh ke bumi yang memberikan kesuburan pada tanah atau Penerima Dara (A. Lerebulan, 2011:35).

Buadaya Duan Lolat mengandung norma/nilai dari tradisi yang hidup di Kepulauan Tanimbar dalam mengatur "hubungan darah" dari sebuah perkawinan suami/laki-laki dan isteri/perempuan yang 
berlangsung secara terus-menerus. Duan merupakan garis turunan dari Ibu, apabila dalam sebuah keluarga tidak ada anak perempuan, maka hubungan tersebut otomatis terputus. Apabila anak laki-laki, maka para Duan harus bayar adat sehingga anak perempuan diserahkan kepada Duan (anak perempuan ganti tempat berupa benda adat). Seseorang yang berada dalam suatu hubungan darah (Duan Lolat) tidak boleh saling menikah (Reressy, 2014).

Keberadaan Budaya Duan Lolat dalam Masyarakat Tanimbar

Kearifan lokal budaya Duan Lolat ini telah dituangkan dalam Peraturan Daerah Kabupaten Maluku Tenggara

Barat No. 28 tahun 2002 tentang Lambang Daerah Kabupaten MTB yang sangat mempengaruhi tata kelakuan dan berfungsi dalam mengatur perbuatan seluruh lapisan masyarakat di wilayah Maluku Tenggara Barat dalam rangka memperkuat karakteristik masyarakat. Nilai-nilai yang muncul dalam keterikatan ini mengandung unsur "hak" dan "kewajiban" yang sangat mulia. Nilai-nilai sosial dalam kultur Duan Lolat merupakan norma-norma sosial yang mengatur hak dan mewajibkan dalam hubungan Duan Lolat sebagai tatanan masyarakat untuk menjaga integritas daerah dan bangsa.

Dalam prakteknya budaya Duan Lolat menjadi sarana yang efektif untuk menghubungkan jaringan-jaringan sosial yang dimiliki oleh individu dan kelompokkelompok sosialnya. Peran dan fungsi budaya Duan Lolat tersebut jelas untuk menciptakan dan mengorganisir setiap jaringan sosial baik yang bersifat umum dan sebaliknya yang bersifat khusus. Untuk hubungan ini, apabila dilihat secara positif dapat digambarkan adanya kemitraan, nilai kesatuan, nilai persaudaraan serta pembagian tugas dan tanggung jawab. Namun mempunyai sisi negatif yaitu hukum positif lemah membuka peluang untuk terjadinya $\mathrm{KKN}$.

\section{METODE PENELITIAN}

Penelitian ini mengunakan pendekatan deskriptif kualitatif dimana penelitian dilakukan untuk mengumpulkan data dan fakta-fakta data di lapangan dari tokoh masyarakat, tokoh Adat dan tokoh Agama, yang berhubungan erat dengan objek penelitian kemudian dilukiskan dan dianalisis berdasarkan kaidah-kaidah ilmu pengetahuan yang relevan di Desa Olilit dan Desa Sifnana. Informan (informant) dalam penelitian ini yaitu Kepala Desa, tokoh masyarakat, tokoh agama, tokoh adat titak resmi (informal opinion leader) maupun tokoh masyarakat resmi (formal opinion leader) sebagai informan kunci dipilih dari masing masing masing-masing lokasi penelitian dengan dengan mengunakan teknik purposive sampling. Kemudian data yang dikumpulkan dikaji dengan Reduksi 
Data, Display Data, Verifikasi dan kesimpulan. Sedangkan Teknik validitas data gunakan yakni Teknik triangulasi yaitu Triangulasi Sumber, Triangulasi Teknik, dan Triangulasi Waktu.

\section{PEMBAHASAN}

\section{Kilas Pandang Tanimbar}

Tanimbar merupakan nama sebuah dari gugusan kepulauan yang dari pulau Yamdena, Larat, Fordata, Selaru, Seira dan pulau-pulau lainnya. Gugusan kepulauan ini yang disebut sebagai Kepulauan Tanimbar, tepat berada di Propinsi Maluku. Kepulauan ini sekarang sudah menjadi sebuah daerah otonom baru yang bernama Kabupaten Maluku Tenggara Barat (MTB berdasarkan Undang-undang Nomor 6 Tahun 2000 tentang Perubahan Undang-undang Nomor 46 Tahun 1999 tentang Pembentukan Propinsi Maluku Utara, Kabupaten Buru dan Kabupaten Maluku Tenggara Barat. Mayoritas penduduknya menghuni Pulau Yamdena, Larat, Fordata, Selaru dan Seira. Penduduk Kabupaten Maluku Tenggara Barat mayoritas berasal dari suku Tanimbar, dari mana datangnya orang-orang Tanimbar tidak dapat ditentukan dengan pasti. Sangat besar kemungkinan mereka datang dari Barat, mungkin ketika gugusan pulau-pulau masih merupakan suatu kontinen dengan pulau-pulau Sunda Besar bersama-sama dengan Timor dan Flores. Mengenai roman orang-orang Tanimbar, harus digolongkan pada bangsa Melayu dengan sedikit atau bukan campuran asing. Semua insan penghuni kepualauan ini setuju menyebut dirinya sebagai "Orang Tanimbar" namun dapat juga dikategorisasikan penamaannya berdasarkan nama pulau dan Desa yang mereka diami (Drabbe dalam Wuritimur 2012). Ini menjukan bahwa masyarakat Tanimbar adalah kumpulan masyarakat adat yang dalam keseharian hidupnya selalu berpegang teguh pada sistem budaya lokal yang berlaku. Perilaku hidup mereka terusmenerus ditunjukan, dan selalu dilandaskan pada budaya yang dianut.

\section{Konsep Duan-Lolat}

Istilah Duan-Lolat merupakan sebuah istilah yang sudah ada sejak lama terdapat dalam budaya dan adat masyarakat Tanimbar yang menunjukan suatu hubungan kekerabatan yang terjadi melalui perkawinan, dimana Duan itu adalah kelompok keluarga yang memberikan anak darah/ anak gadis (perempuan) dan Lolat itu adalah kelompok keluarga yang menerima anak perempuan.

Ketika konsep ini dikonfirmasikan dengan salah satu Tokoh Adat Desa Sifnana "Bapak GK" mengatakah bahwa :

"Duan lolat adalah hubungan kekeluargaan yang dibangun atas dasar atas dasar sistem perkawinan dimana Duan berarti Saudara lakilaki dari pihak ibu atau pihak yang memberikan anak perempuan dan Lolat berarti anak dari keluarganya 
saudara perempuan atau yang menerima perempuan"

Dengan terjadinya hubungan perkawinan ini maka konsekuensi yang diterima adalah adanya tanggungjawab timbal balik yang terjadi dari kedua bela pihak baik dari pihak Duan maupun dari Pihak Lolat. Mengenai hal ini dapat digambarkan pola hubungan antar Duan dan Lolat sebagai suatu ikatan kekeluargaan yang menganut hubungan timbal balik antar ke duanya sebagai berikut ;

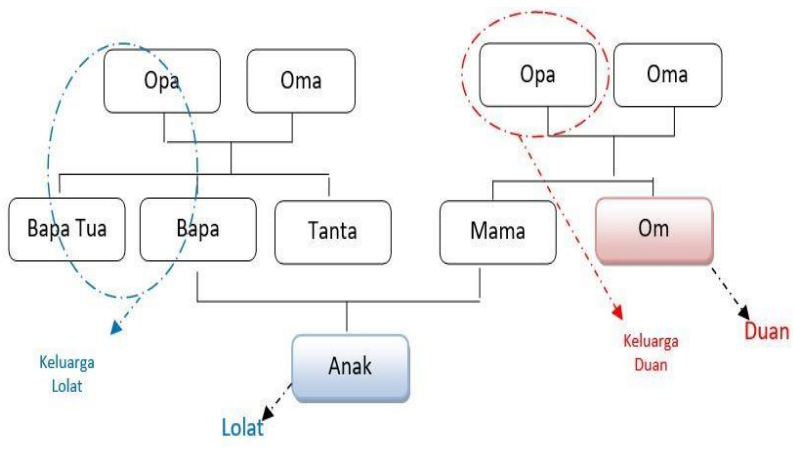

Skema1 Hubungan Duan Lolat

\section{a. Pengertian Duan}

Kata Duan dalam bahasa SeiraLarat-Fordata disebut Dua, dalam bahasa Yamdena disebut nduwe, nduan, nduin yang secara harafia berarti Tuan, Pemilik dari sesuatu barang (Rumah, kampung, lahan perkebunan, hutan dan pulau) yang berfungsi untuk melindung barang tersebut (Wuritimur, 2012 dan Lerebulan 2011). Dalam artian yang lain Duan adalah tanah dan Lolat adalah hujan. Lolat disimbolkan dengan hujan yang jatuh ke bumi yang memberikan kesuburan pada tanah. Duan besar yaitu
Tuhan dan manusia adalah Lolat. Duan berarti Pemberi Dara, sedangkan Lolat berarti Penerima Dara (Usmani, 2015)

Dalam konteks kekerabatan, Duan adalah pemilik atas Lolat karena menurut orang Tanimbar mereka berasal dari dia artinya Duanlah yang memberikan perempuan dalam suatu perkawinan yang akan meberikan keturunan atau anak (Lolat). Sebagai pemberi perempuan dalam perkawinan maka Duan bagi orang Tanimbar dinamakan Ompak Ain yang artinya tempat atau tanah dimana tumbuhnya tumbuh-tumbuhan dan tanaman.

\section{b. Pengertian Lolat}

Istilah Lolat secara harafia berarti Jajaran atau Barisan yang artinya suatu jajaran atau barisan rumah-rumah pengambil istri. Artinya lolat baru disebut Lolat jika sudah mengambil istri dari rumah yang sama, dalam hal ini dari duan-nya sampai tiga generasi atau lebih. Jadi lolat lebih menunjuk pada jajaran-jajaran rumah kaum laki-laki yang membangun suatu persekutuan melalui perkawinan. Lolat bisa juga disebut oleh masyarakat Tanimbar sebagai udan ain yang aratinya tempat hujan atau tempat dimana hujan berasal, bahkan disimbolkan sebagai "hujan" itu. Maksusdnya lolat dipandang sebagai tempat dari mana datanggnya hujan untuk menyuburkan tanah sehingga tanaman dapat tumbuh. Dalam pengertian yang 
lainnya lolat diartikan sebagai penerima anak gadis perempuan (Wuritimur,Pr 2012)

\section{Pengelompokan Duan}

Hubungan kekerabatan Duan Lolat bukanlah suatu hubungan yang biasa tanpa disertai dengan suatu nilai yang menjiwai dan terkandung didalammnya. Nilai tersebut akan sangat kelihatan berdasaran tannggujawab pada Duan-duan tersebut. Setiap orang yang berasal dari Tanimbar pasti mempunyai Duan, sehingga dilihat dari garis keturunnnya, maka ada dua macam Duan yaitu Duan lir branal/merwane yang berasal dari pihak laki-laki atau berdasarkan pada garis keturunan Ayah dan Duan lir vate/bate yang berasal dari pihak perempuan berdasarkan garis pada keturunan ibu. Sementara itu peneglompokan Lolat dalam budaya Tanimbar biasanya tidak dibedakan secara tegas pada kelompok Duan. Umumnya anak laki-laki lebih diperhitungkan karena merekalah yang sering terlibat dalam pembicaraan adat, sementara anak perempuan pada saatnya mereka akan menikah dan meninggalkan keluarga (Wuritimur Pr, 2012)

Dengan melihat pada peneglompokan Duan di atas maka berdasarkan kategorinya dapat dibedakan menjadi tiga jenis antara lain : Duan Ompak Ain yaitu Duan dari garis turunan perempuan/ Ibu (matrilinial), Duan Udan Ain yaitu Duan dari garis turunan Laki-laki/ Bapak dan Duan Empu
Ain yaitu Duan dari garis turunan moyang ( kakek) pihak Bapak yang merupakan leluhur dan menjadi titik pusat dan awal keturunan. Hal ini sesuai hasil wawancara dengan dengan Bapak "GK" yang merupakan salah satu Tokoh Adat Desa Sifnana yang mengatakan bahwa :

"Tradisi perkawinan dalam bingkai duan lolat adalah Duan memberi atau menerima harta kawin yang dapat diklasisfikasikan sebagai berikut : Duan Ompak Ain membayar Lele, Duan Udan Ain membayar Lelbutir dan Duan Empu Ain membayar Mase. Sedangkan Lolat diposisikan sebagai pihak yang berkewajiban menghidupi Duan melalui kewajiban adat yang dilimpahkan"

Untuk mengetehui lebih jelas tentang ke tiga kelompok Duan ini maka akan dijelaskan secara rinci pola dan hubungannya agar lebih mudah untuk dipahami :

\section{a. Duan Ompak Ain}

Inilah Duan dari garis keturunan Ibu yang dalam bahasa Tanimbar 'Ompak' berarti tanah atau bumi dan 'ain' berarti sumber atau asal. Duan Ompak Ain ini juga bisa disebut sebagai Duan Lele (harta muka) karena bila anak laki-laki (keponakan) akan menikah maka harta kawin yang akan diberikan sebagai tanggungjawabnya berupa Lele (gading gajah) kepada Duan Ompak Ain pihak perempuan. Jika digambarkan maka skema dan polanya adalah sebagai berikut : 


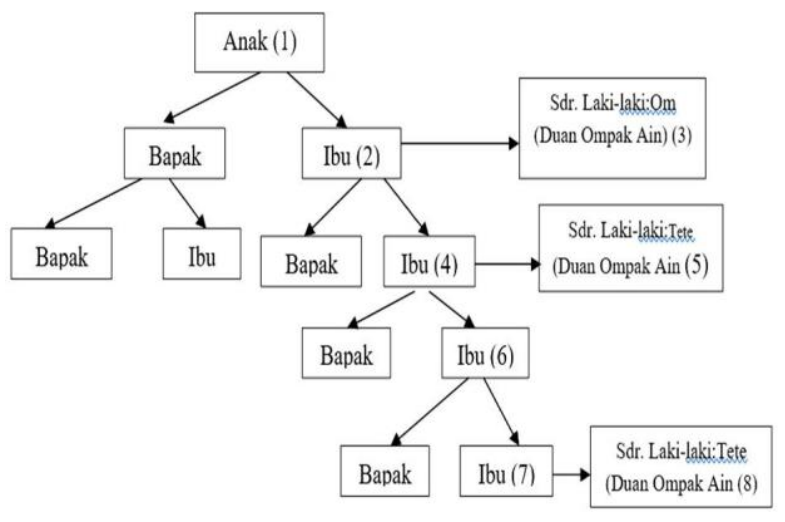

Skema 2. Duan Ompak Ain

Dari skema diatas maka dapat dijelaskan pola garis keturunnya sebagai berikut: Anak (1) panya Mama (2) punya saudara laki-laki atau Om (3) disebut sebagai Duan Ompak Ain Pertama. Bila ditarik lebih jauh maka kita akan menemukan pola : Anak (1) panya Mama (2) punya mama (4) punya saudara lakilaki: Tete (5) disebut juga sebagai Duan dari Ibu. Atau juga Anak (1) panya Mama (2) punya mama (4) punya mama (6) punya mama (7) punya saudara laki-laki: Tete (8) maka tetap disebut Duan Ompak Ain, yang akan berlangsung terus menerus sampai turunan berapapun asal dihitung dari garis keturunan perempuan. Hal tidak berlaku untuk anak laki-laki kerena kelak Duan dari anak laki-laki bisa berubah.

\section{b. Duan Udan Ain}

Inilah Duan yang berasal dari garis keturunan Laki-laki/ Bapak. Udan ain artinya tempat dari mana datangnya hujan atau tempat pencurahan hujan. Terkadang Duan Udan Ain juga disebut sebagai Duan Lelbutir (harta tengah) karena harta yang menjadi tangggungjawabnya dalam perkawinan adalah lelbutir atau antinganting. Adapun skema dan polanya dapat digambarkan sebagai berikut :

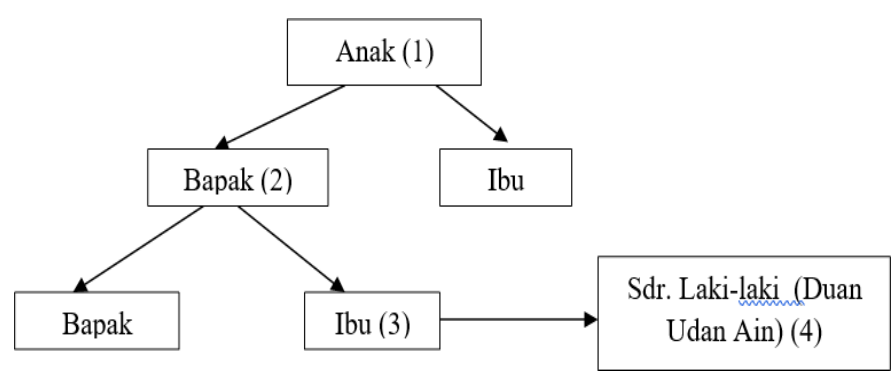

Skema 3. Duan Udan Ain

Dari skema diatas maka dapat dijelaskan pola garis keturunnya sebagai berikut: Anak (1) panya Bapa (2) punya Mama (3) punya saudara aki-laki disebut sebagai Duan Udan Ain atau Duan dari Bapa (Bapa punya Duan)

\section{c. Duan Empu Ain}

Inilah Duan yang berasal dari moyang Laki-laki (Kakek) garis keturunan pihak Bapa. Biasanya disebut juga sebagai Duan Mase (harta belakang) sebab harta kawin yang akan menjadi tanggungjawabnya dalam perkawinan adalah emas. Adapun skema dan polanya dapat digambarkan sebagai berikut :

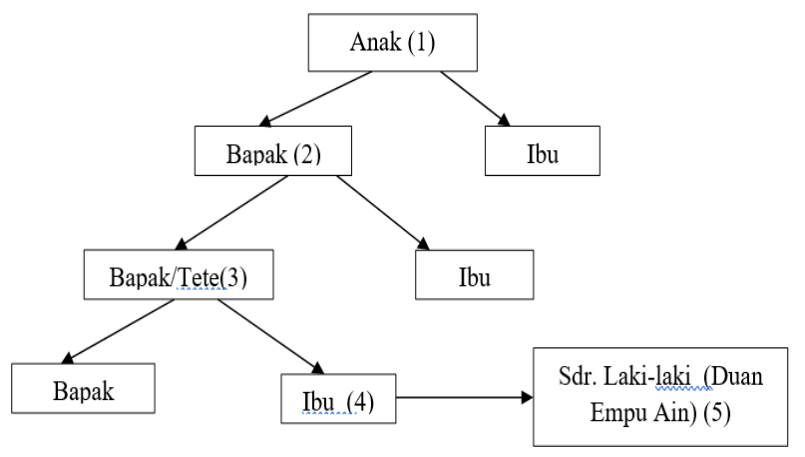

Skema 4. Duan Empu Ain dari garis Bapa (pemberi harta) 
Dari skema diatas dapat dijelaskan pola penyebarannya adalah sebagai berikut: Anak (1) punya Bapa (2) punya Bapa/Tete (3) punya Mama (4) punya saudara lakilaki Tete (5) disebut sebagai Duan Empu Ain atau Duan Mase.

Selain Duan Empu Ain yang telah dijelaskan diatas, masyarkat Tanimbar juga masih mengenal Duan Empu Ain (Tete) yang berasal dari garis keturunan Ibu. Namun dalam pembicaraan adat yang menyangkut harta kawin, Duan ini tidak bisa dilibatkan sebab Ibu sudah masuk dalam anggota keluarga Bapa (Suaminya). Duan ini hanya dilibatkan dalam acara kematian karena harta kawin adalah kewajiban pihak keluarga Bapa sehingga pembicaraan tentang Duan Empu Ain lebih tertuju Duan Tete dari Bapa (Lerebulan, MSC 2011:42). Adapun Skema dan Polanya dapat dijelaskan sebagai berikut:

Skema 5. Duan Empu Ain dari garis Ibu

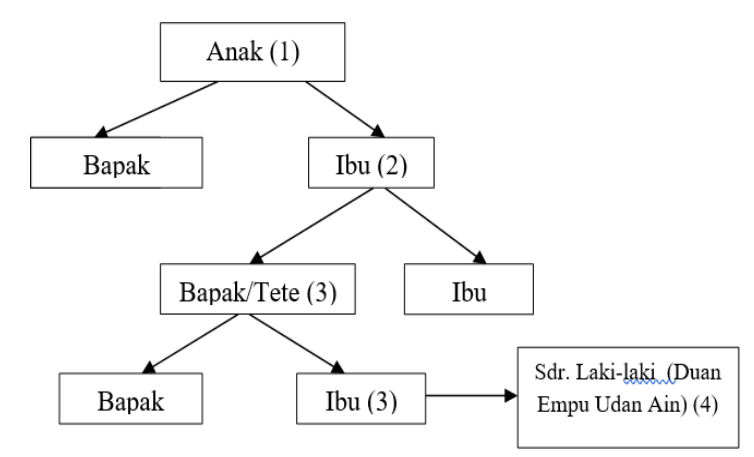

\section{Skema 5. Duan Empu Ain dari garis Ibu}

Dari skema diatas dapat dijelaskan pola penyebarannya adalah sebagai berikut:
Anak
(1) punya Mama
(2) punya
Bapa/Tete
(3) punya Mama
(4) punya

saudara laki-laki Tete (5) disebut sebagai Duan Empu Ain atau Duan Mase yang tidak terlibat dalam urusan harta kawin.

Dengan demikian dari skema dan pola yang digambarkan diatas untuk menunjukan posisi dan kedudukan dari Duan Ompak Ain, Duan Udan Ain dan Duan Empu Ain maka kita akan dengan mudah untuk memahaminya. Selanjutnya akan digambarkan skema secara keseluran yang menunjukan posisi dari pada Duan-Duan tersebut.

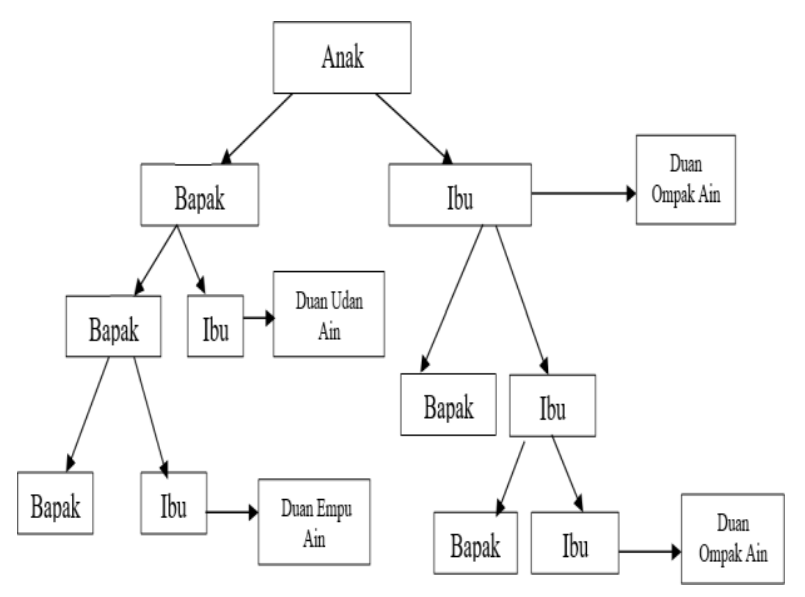

\section{Skema 6. Posisi Duan}

Pola-pola dan struktur kekerabatan yang dijelaskan diatas dibangun berdasarkan tradisi perkawinan adat. Pola perkawinan dimaksud adalah sebuah pola perkawinan yang didasarkan pada garis keturunan ibubapak (parental). Garis keturunan yang demikian ini terjadi dan disebabkan karena adanya ikatan kekeluargaan yang diprakarsai oleh kuatnya hubungan persaudaraan antara saudara-bersaudara dan secara khusus terhadap hubungan dari (saudara kandung). Budaya tersebut kemudian melahirkan suatu relasi yang 
kaku dan terstruktur secara hirarkis yang mengakibatkan Duan cenderung merasa dan memahami dirinya berada pada posisi superordinat, dan Lolat tersubordinasi di bawahnya.

\section{Terbentukanya Hubungan Duan-Lolat}

Terbentuknya sebuah hubungan sosial kekerabatan sangat dipengaruhi oleh berbabagai faktor baik yang terjadi secara internal dari komunitas itu sendiri maupun bisa juga berasal dari faktor eksternal. Hubungan kekerabatan yang dimaksud biasanya dalam ilmu sosial disebut sebagai hubungan yang terbagun atas dasar solidaritas mekanik diamana suatau komunitas akan bergerak secara mekanik untuk memberikan bantuan manakala ada peristiwa tertentu yang terjadi baik dalam suka maupun duka karena adanya rasa solidaritas yang tinggi diantara mereka.

Jalinan hubungan ini tentunya merupakan satu kesatuan masyarakat sudah terbagun sebelumnya oleh pranata sosial yang sudah melembaga dalam kehidupan mereka dan dapat dijadikan sebagai sebuah kebiasaan untuk mengatur hubungan sosial diantara mereka. Sehingga menimbulkan suatu kesepakan dan komitmen untuk saling membantu dan melindungi bahkan sama-sama mencari solusi meskipun tidak saling mengenal satu dengan yang lainnya.

Hubungan kekerabatan tersebut bagi masyarakat Tanimbar dikenal dengan hubungan Duan-Lolat seperti yang dikatakakan oleh satu tokoh adat Desa Olilit bahwa :

'hubungan sosial duan lolat adalah sebuah hubungan yang telah melembaga sejak dulu yang dijadikan sebagai sebuah kebiasaan untuk mengatur norma dan nilai dalam hubungan kemasyarakatan. Hubungan ini dijadikan sebagai sebuah komitmen dan kesepakatan untuk salaing melindungi, tolong menolong dan sama-sama mencari solusi jika ada permasalahan yang menimpa mereka'.

Hubungan Duan Lolat ini menjadi bagian yang sangat penting bagi orang Tanimbar secara umum termasuk Desa Olilit dan Desa Sifnana. Sejak dulu masyarakat sudah mengenal budaya tolong menolong solidaritas sosial yang tumbuh dan melekat dalam budaya Duan-Lolat dimana adanya rasa kebersamaan untuk memberikan tanggungan masing-masing baik sebagai Duan maupun Lolat pada keluarga yang mempunyai hajatan. Hal ini terlihat dari hasil Wawancara dengan Ketua Adat Desa Olilit (Bapak TS) yang mengatakan bahwa :

Duan lolat dalam pemahaman masyarakat Tanimbar dipahami sebagai sebuah hubungan kekeluargaan yang dipengaruhi oleh adanya ikatan perkawianan, dengan menggunkan bahasa Yamdena dikatakan Duan Lolat ne ye namiana fali fasa we nwayat. E feti kufsau kor uram bate, ne kete yak ye ku Lolat ber ko ma ko mundru beryak. artinya (duan Loat itu ada karena adanya perkawian, misalnya kalau saya menikah maka saudara perempuanmu, maka saya akan menjadi Lolat untukmu, dan Kamu akan menjadi Duan untukku). 
Selain konsep Duan Lolat yang telah dijelaskan diatas, maka dalam kehidupan masyarakat, adat Tanimbar dipahami juga sebagai hubungan kekeluargaan yang dibangun atas dasar adanya kesepakatan bersama yang dibuat oleh masyarakat. Dikatakan bahwa "fasawe nwayat ma Duan lolat ne namin nempa selain fasawe ne ye, makenar rose kai ye fali rampeang sir ma ral sir relu ai wai ma rasalan sir. Tetetak ne ye rose ma felam ndrue ma Lolat, maka morip e ralompay sir dedesar artinya ( perkawinan menjadi alasan hadirnya hubungan Duan dan Lolat. Akan tetapi orang tua-tua dulu sudah membuat ikatan duan lolat dalam bentuk kesepakatan bersama sebagai saudara untuk saling menolong satu dengan yang lain.

Dengan adanya perkawinan maka terjadilah ikatan kekerabatan Duan dan Lolat yang baru yang tidak hanya melibatkan lakilaki dan perempuan yang kawin, tetapi juga keluarga masing-masing. Lewat perkawinan ini maka semua keluarga dari kedua belah pihak saling berbagi dan saling menolong dalam suka maupun duka. Hal ini tentunya sangat terasa jika pasangan suami dan istri yang baru itu mengalami gejolak yang berpotensi untuk membahayakan ketuhuan rumah tangganya, maka orang tua dan saudara-saudara dari pasangan baru itu sudah terlebih dahulu berinsisiatif untuk menyelesaikan permasalahan yang dialami itu lebih dini secara kekeluaragaan. Jika inisiatif itu tidak berhasil untuk meredahkan permasalahan tersebut maka komunikasi dapat mereka tingatkan dengan melibatkan
Duan dan Lolat diamana mereka saling berhadapan yang melibatkan juga piha Duan dan Lolat dari kedua belah pihak untuk menyelesaikan permasalahan tersebut (Wuritimur, Pr 2012)

Dalam hal ini mereka menyebutnya dengan nama Tampa Kawin "fatlima" artinya hubungan yang akan dibagun ke jenjang perkawinan berikutnya masingmasing pihak harus melihat dan menyadari dimanakah posisinya, sebagai Duan atau Lolat. Hal ini menunjukan bahwa jika lakilaki dari keluarga Lolat maka bisa mencari pasangan perempuan dari keluarga Duan karena itulah tempat kawinya bukan sebaliknya sehingga tanggungjawabnya untuk membrikan "Sopi" atau minuman khas Tanimbar tetap berlanjut kepada pihak Duan. Inilah yang biasanya disebut dengan perkawinan ideal tetapi jika terjadi sebaliknya maka tanggungjawabnya sebagai Duan yang harus menerima Sopi dari Lolat sesasai karena statusnya sekarang berganti menjadi Lolat.

Jika perkawinan yang ideal itu tidak terjadi maka dapat disebut sebagai penyimpangan karena mereka lupa akan status sosialnya sebagai Duan. Penyimpangan ini dapat diatasi kalau masing-masing sebelum membangun relasi harus terbuka kepada orang tuanya. Oleh sebab itu baik orang Olilt maupun Orang Sifnana sangat menghargai hubungan Duan Lolat tersebut karena saudaranya perempuan 
itu dapat memberikan status Duan bagi mereka dan sebaliknya

\section{Peranan dan Tanggung Jawab Duan dan}

\section{Lolat}

Secara keseluruhan telah dijelaskan hubungan kekerabatan yang terjadi diantara Duan dan Lolat yang ada dalam masyarakat Tanimbar khususnya di Desa Olilit dan Desa Sifnana. Namun semuanya itu belumlah cukup karena belum dijelaskannya peran Duan dan Lolat itu, yang mengambarkan tugas, tanggungjawab dan kewajibannya baik diluar pembicaraan (ngriye) adat maupun didalam pembicaraan adat.

Tanggung jawab diluar pembicaraan adat itu berkaitan dengan kehidupan seharihari dimasyarakat dimana Duan dapat memberikan bantuan kepada Lolat atau sebaliknya seperti yang dikatakan oleh Bapak 'NF' salah satu Tokoh masyarakat Desa Olilit bahwa :

Peran hari-hari sebagai tanggungjawab adalah Duan memberi makan (pauknya saja) dan pakai karena Duan statusnya sangat tinggi daripada Lolat. Sebab dalam hubungan adat, kalau Duan marah pasti Lolat sakit. Apabila Lolat datang menemui Duan dengan membawa sopi, maka Duan bertanggungjawab untuk memenuhi kebutuhan Lolat.lebilanjut dikatakan bahwa seorang Duan atau Lolat sudah harus memahami apa kewajibannya dan apa yang akan diterimanya sebagai haknya. Duan memberi hidup bagi lolat, nilainya m u n g k i n sangat terbatas. Apabila Duan buang Lolat karena satu hal, pada saat Duan salah maka lolat dapat mengambil langkah dengan jalan mengelu kepada Duan yang lebih tinggi/ke atas.

Hal yang sama juga dikatakan salah masyarakat Desa Olili bahwa :

Konsep hubungan duan lolat ini tidak saja ada dalam hubungan perkawinan dalam setiah peristiwa yang berlangsung ditengah-tengah masyarakat Tanimbar, muali dari sejak kelahiran sampai dengan peristiwa kematian dan pembangunan rumah. Biasanya dalam peristiwa-peristiwa tersebut masing-masing sudah harus mengatahui hak dan kewajibannya baik sebagai pihak Duan biasanya berkewajiban untuk memberikan pakaian dan perlengkapannya, sementara pihak lolat berkewajiban memberikan lauk-pauk seperti daging dan minuman khas Tanimbar yaitu Sopi.

Ini menunjukan bahwa jika Lolat ada dalam situasi yang terpuruk seperti gagal panen, tidak mempunyai bibit untuk ladang baru maka Lolat dapat meminta bantuan kepada Duan dengan memberikan sopi, daging babi atau ikan sebagai pengikat terhadap apa yang dimintanya. Tanggungjawab ini juga terkadang diberikan kepada kepada Lolat dalam bidang pendididikan dan kesehatan, apabila ada kekurangan biaya maka Duan dapat membantu memberikan uang atau membantu dengan memberikan Dusun kelapa Lolat untuk dikerjakan. Situasi seperti ini akan terus berlanjut dalam kehidupan adat orang tanimbar untuk saling melengkapi satu dengan yang lainya karena adanya 
keterikatan buadaya Duan dan Lolatnya.

Dalam proses pembicaraan adat orang Tanimbar yang telah dijelaskan diatas baik yang sifatnya kecil maupun yang sifatnya besar selalu ada peran yang menunjukan tugas dan tanggungjawab baik sebagai Duan maupun Lolat sejak mualai dari proses kelahiran sampai dengan proses kematian. Namun ada tiga bidang sentral yang sering dijadikan sebagai ukuran untuk menunjukan tugas dan tanggungjawab baik sebagai Duan terhadap Lolat yaitu Perkawian Adat, Kematian dan Pembangunan Rumah.

Ini sesuai dengan hasil wawancara yang dilakukan dengan Tokoh adat Desa Olilit dan Sifnana mengatakan bahwa :

"fasawe ma mangmwate ma adat dalam e lolo mose ma tafaik kayar re. Ma na momorip biase ye kayar ye (Duan Lolat) lo rafmpwane lo" (perkawinan dan kematian dalam proses adat masih dihadapi. Sedangkan dalam kehidupan biasa, umumnya hat itu (Duan Lolat) tidak lagi dihadapi).

\section{Jenis serta Hak dan Kewajiban}

Umumnya yang terlihat dalam pembicaraan adat pada kedua Desa tersebut hanya berkaitan dengan tiga bidang sentaral yang telah dijelaskan sebulmnya diatas yaitu:

\section{a. Bidang Perkawinan}

Seperti yang telah dijelaskan sebelumnya bahwa hubungan kekerabatan Duan Lolat itu terbentuk melalui sebuah perkawinan, sehingga dari hubungan itulah melekat didalammnya hak dan kewajiban masing-masing Duan terhadap Lolat yaitu :

1) Duan Ompak Ain mempunyai Hak menerima harta kawin anak perempuan dari pasangan suami-istri dan berkewajiban untuk membayar harta kawin anak laki- laki. Harta kawinnya "Bain Lele" atau Harta Muka berupa harta gigi gajah yang panjangnya satu depa orang dewasa sebagai perlengkapan adat dan uang Rp. 250.000. Bila tidak ada maka dapat diuangkan dengan nilai sebesar Rp.2.500.000 (dua juta lima ratus ribu rupiah) seseuai kesepakatan adat

2) Duan Udan Ain, mempunyai Hak menerima harta kawin dari anak perempuan (pasangan suami-istri) dan Kewajiban untuk membayar harta kawin dari anak laki-laki. Harta kawinnya disebut "Bain Lelbutir" atau Harta Tengah berupa sepasang anting-anting yang kadar emasnya tinggi dengan perlengkapan adat sesuai kesepakatan dan uang (Rp. 150.000,-). Harta ini dapat diuangkan dengan nilai kesepakatan sebesar 1.500.000 (satu juta lima ratus ribu rupiah)

3) D u a n Empu Ain berhak menerima harta kawin dari anak perempuan dan berkewajiban membayar harta kawin dari anak laki-laki. Harta kawinnya disebut "Duan Mase" atau Harta Belakang berupa adat harta emas yang sungguh murni dengan perlengkapan 
adat sesuai kesepakatan dan uang (Rp. 100.000,-). Harta ini dapat diuangkan dengan nilai kespakatan sebesar

\subsubsection{0 (satu Juta Rupiah)}

Semua hak dan kewajiban yang ada pada Harta Muka, Harta Tengah dan Harta Belakang menunjkan bahwa simbol perkawinan sebagai sebuah bahtera yang tetap harus dijaga dan dipelihara oleh suami dan istri. Pada umumnya setiap setiap keluarga perempuan menghendaki harta kawin dalam bentuk bahan-bahan adat (lele, lelbutir dan mase). Namun saat ini barangbarang tersebut sudah sulit untuk ditemukan sehingga dapat dikonfersikan kedalam nilai nominal sesuai kespakatan adat seperti yang telah dijelaskan diatas. Namun nilai itu dapat mengalami perubahan sejalan dengan perubahan dan perkembangan ekonomi masyarakat (Lerebulan, MSC 2011).

\section{b. Pembangunan Rumah}

Kewajiban dan tanggungjawab itu dinyatakan pada saat :

1) Peletakan Batu Pertama dan Pendirian Rumah

2) Penutupan Atap Rumahuan

3) Syukuran Masuk Rumah Baru

Setelah semua proses pembangunan rumah selesai maka semua Duan dan Lolat akan berkumpul untuk melakukan syukuran atau berdoa kepada Tuhan sebelum rumah ditempati. Dalam proses ini biasanya masing-masing pihak baik Duan maupun Lolat sudah mengetahui tugas dan tanggungjawabnya dimana Lolat akan membawah Sopi dan Uang seadanya (sumbat Sopi) sedangakan Duan Ompak Ain, Udan Ain dan Empu Ain akan berembuk bersama untuk membuat pembagian tentang apa yang harus dibawah berupa tanggungan mereka seperti Kain Tenun, Besar dan Uang

\section{c. Acara Kematian}

Sementara itu pada acara kematian orang yang sudah menikah dan sudah usia lanjut maka semua Duan dan Lolat akan diberi tahu untuk mebawah tanggungannya. Lolat dari pihak yang meninggal akan membawah ikan atau babi, sedangkan Duannya akan membawakan makanan, pakaian dan sarung, terutama Duan pertama totolir tabun (menurunkan apa yang menjadi alas, dasar dan inti) yang berupa sebuah kalung atau anting-anting yang terbuat dari emas. (Wuritimur, Pr 2012)

Kewajiban dan tanggungjawab yang tersimbol dari berbagai bentuk barang pemberian itu, baik dari pihak Duan maupun Lolat seperti yang telah dijelakan diatas saat ini telah mengalami pergesesaran karena adanya perkembaangan dari waktu kewaktu sehingga sangat disesuaikan dengan kondisi dan peristiwa kehidupan yang dialami.

\section{Makna dalam Hubungan Duan Lolat}

Hubungan yang terjadi antara Duan dan Lolat dapat memberikan makna sebagai berikut :

a. Solidaritas sosial, bertumbuh dari 
kekeluargaan yang muncul lewat hubungan darah (darah sebagai lambang hidup) dilihat dari sisi perempuan. Dalam budaya Duan Lolat apabila ada masalah (beban ataupun acara keluarga), cukup dengan pengakuan dari yang bersangkutan (pelaku), sehingga yang menanggung adalah Duan

b. Dimensi persekutuan dalam keluarga, karena darah yang ditarik dalam suatu persekutuan dari dua keluarga menjadi satu. Perkawinan yang terjadi antara pria dan wanita, menarik kedua belah pihak kedalam suatu ikatan kekeluargaan yang erat secara turun-temurun. Sehingga terjalin hubungan untuk saling bertanggungjawab, tercipta kerjasama dalam kehidupan bersama.

c. Nilai memberi hidup, Duan bertanggungjawab terhadap Lolat, suka atau tidak merupakan kewajiban. Duan melindungi hidup juga memberi hidup. Setiap nilai harus mengorbankan nilai-nilai lain, Duan bertanggungjawab terhadap Lolat sampai mati sehingga Lolat wajib menjaga hidup yang berasal atau diberikan Duan.

\section{PENUTUP}

\section{Kesimpulan}

1. Kehidupan Masyarakat Tanimbar saat ini masih sangat terikat hubungan kekerabatan Duan Lolat yang dijadikan sebagai pranata sosial dalam kehidupan bermasyarakat. Hal ini sangat jelas terlihat ketika terjadinya hubungan perkawinan dimana pihak yang memberikan anak perempuan diposisikan sebagai Duan dan pihak yang menerima anak perempuan diposisikan sebagai Lolat. Dengan adanya posisi tersebut maka konsekuensi yang diterima adalah adanya tanggungjawab timbal balik yang terjadi dari kedua bela pihak baik dari pihak baik sebagai Duan maupun Lolat dalam setiap pembicaraan adat

2. Segala bentuk keputusan Duan misalnya penuntutan harta kawin yang sudah diatur dalam hukum perkawinan adat oleh Duan tidak bisa di batalkan oleh Lolat. Untuk itu seorang Duan atau Lolat sudah memahami apa kewajibannya dan apa yang akan diterimanya sebagai haknya.

3. Umumnya dalam praktek perkawinan yang berlaku, sering terjadi saling tukar menukar barang antara kelompok Duan dan kelompok Lolat. Pihak duan biasanya berkewajiban untuk memberikan pakaian dan perlengkapannya, termasuk juga bahan makanan berupa beras dan umbi- umbian, kepada pihak lolat. Sementara itu, pihak lolat berkewajiban untuk memberikan lauk-pauk seperti daging dan minuman sopi (tuak khas Tanimbar) kepada pihak duan. Barang yang diberikan, entah oleh pihak duan 
maupun lolat, juga bisa dalam bentuk benda-benda adat seperti kain tenun, perhiasan adat, gading gajah, dll, yang disesuaikan dengan peristiwa kehidupan yang sementara dihadapi.

\section{Saran}

1. Perlunya pembentukan lembaga adat dalam masyarakat Tanimbar agar dapat mengatur permasalahan yang terjadi khususnya yang berkaitan dengan tanggungjawab sebagai Duan dan Lolat karena harta kawin yang saat ini sudah tidak sesuai lagi dengan kondisi saat ini

2. Perlunya perhatian yang diberikan oleh Pemerintah Daerah Maluku Tenggara Barat melalui dinas atau lembaga terkait guna mengupayakan pemeliharaan budaya masyarakat adat setempat di dalam membangun kehidupan masyarakat yang damai

3. Agar setiap kekuatan lembaga adat yang dimiliki dapat mempengaruhi terciptanya kehidupan masyarakat yang harmonis meski berbeda pada wilayah perkampungan atau desa yang berbeda.

4. Setiap kebenaran budaya dari ceritera sejarah hendaknya dapat di bukukan sehingga dapat dipelajari oleh setiap Generasi dalam memahami kehidupan budaya masyarakat adat sebelumnya.

\section{DAFTAR PUSTAKA}

Abdullah, I. (2006). Konstruksi dan Reproduksi Kebudayaan. Yogyakarta: Pustaka Pelajar.

Fukuyama, Francis. 2003. Social Capital and Economic Development. London: Routledge.

Islami, M. Irfan, 2001. Filsafat Ilmu dan Metodologi Penelitian, Bahan KuliahProgram Doktor Ilmu Admiistrasi Universitas Brawijaya Malang.

Judistira, K.G. (2008). Budaya Sunda: Melintasi Waktu Menentang Masa Depan. Bandung: Lemlit UNPAD.

Koentjaraningrat. (2009). Sejarah Teori Antropologi I. Jakarta: UI Press. Kuntowijoyo, (2006). Budaya dan Masyarakat (Edisi Paripurna). Yogyakarta: Tiara Wacana.

Lerebulan MSC, Aloysius. (2011). Tanimbar; Maluku Tenggara Barat, antara Tradisi dan Kehidupan Modern. Yogyakarta: Kanisius.

Moleong, Lexy J. (2005). Metodologi Penelitian Kualitatif. Edisi Revisi, Bandung: PT.Remaja Rosdakarya.

Mulyana, Deddy. 2001. Metodologi Penelitian Kualitatif, Pradigma Baru Ilmu Komunikasi dan Ilmu Sosial Lainnya, Remaja Rosdakarya : Bandung.

Niode, S.A. (2007). Gorontalo (Perubahan Nilai-Nilai Budaya dan Pranata Sosial). Jakarta: Pustaka Indonesia Press.

Rasid, Yunus. (2014) Nilai-Nilai Kearifan Lokal (Local Genius) Sebagai Penguat Karakter Bangsa, Studi Empiris Tentang Huyula. Yogyakarta: Deepublish. 
Rosidi, A. (2011). Kearifan Lokal dalam Perspektif Budayan Sunda. Bandung: Kiblat Buku Utama..

Supardan, D. (2008). Pengantar Ilmu Sosial Sebuah Kajian Pendekatan Structural. Jakarta: Bumi Aksara.

Syam, F. (2009). Renungan BJ. Habibie Membangun Peradaban
Indonesia. Jakarta, Gema Insani.

Wuritimur Pr, Amrosius (2012). Basudara Orang Tanimbar, Model Kearifan Lokal, Yogyakarta: Kanisius

https://www.kompasiana.com/npreressy/54f7cc00a3 33112a1f8b4a2d/duan-lolat-sebuah-kearifanlokal?page $=$ all

Undang-undang No.28 Tahun 2002 Tentang Lambang Daerah Kabupaten Maluku Tenggara Barat. 
